Egyptian Journal of Aquatic Biology \& Fisheries

Zoology Department, Faculty of Science,

Ain Shams University, Cairo, Egypt.

ISSN $1110-6131$

Vol. 25(1): 443 - 459 (2021)

www.ejabf.journals.ekb.eg

\title{
Phytoplankton Composition and its Biochemical Contents in a Subtropical Reservoir (Lake Nasser, Egypt) during Flood Season.
}

\author{
Shymaa S. Zaher, Howayda H. Abd El-Hady " and Nehad Khalifa \\ National Institute of Oceanography and Fisheries, NIOF, Egypt. \\ "Corresponding Author: howayda999@ hotmail.com
}

\section{ARTICLE INFO}

Article History:

Received: Jan. 3, 2021

Accepted: Jan. 20, 2021

Online: Jan. 28, 2021

\section{Keywords:}

Cyanobacteria,

Bacillariophyceae,

Chlorophyceae,

Proteins,

Carbohydrates,

Lipids.

\begin{abstract}
A major task for categorizing an ecological flood is establishing the effects of environmental enrichment on nutrient availability, which may affect phytoplankton species composition and internal biochemical contents. The current study seeks to analyze the interaction between environmental variables, phytoplankton composition and its internal biochemical content during the flood season at Lake Nasser, Egypt. Samples were collected from four water depths (surface, $10 \mathrm{~m} ., 20 \mathrm{~m}$. and bottom) at five sites along the main channel of Lake Nasser during flood season in August 2017. A major bloom of Cyanobacteria was detected along with retardation of biopolymeric particulate organic carbon availability. Principle component analysis indicated that the most significant parameters affecting total phytoplankton distribution, especially Cyanobacteria, were temperature, dissolved oxygen, nitrite, and phosphate. Moreover, a negative correlation was reported between protein content, organic carbon and total biochemical content with nitrate. The highest biopolymeric particulate organic carbon value $(37.15 \mathrm{mg} / \mathrm{l})$, protein $(88.64 \mathrm{mg} / \mathrm{l})$ and lipid contents $(1.5$ $\mathrm{mg} / \mathrm{l}$ ), were recorded at El-Madiq site with total biochemical content of 91.29 $\mathrm{mg} / \mathrm{l}$ and associated optimum nutrient levels. This interpreted with an increase of Chlorophycean species biomass $\left(812.5 \times 10^{3}\right.$ cell $\left.1^{-1}\right)$. Flood causes an elevation in the minor lipid cellular composition more than carbohydrates at all sites. Flooding in Lake Nasser altered its water quality through introducing oxygen and nutrients, along with changes in phytoplankton species composition and internal biochemical content.
\end{abstract}

\section{INTRODUCTION}

Flooding is an environmental stress that is often triggered in flood-prone environments by natural phenomena such as snowmelt, rainfall, and tides. Human activity, including construction and usage of hydropower and tidal water conservancy projects, may initiate flooding events (Lopez \& Kursar, 1999; Liu et al., 2013) . River flooding may have a negative impact on the aquatic ecosystem that could potentially impact local populations infrastructure, and may result in loss of crops, and promote discharge of raw sewage and industrial waste (Euripidou \& Murray, 2004). However, there are positive aspects of flooding, including increases in dissolved oxygen and 
nutrient supply to aquatic ecosystems, enhancement of fish production, creation of wildlife habitat, rejuvenation of soil fertility, in addition to the productive effects on plant growth and physiological rhythms (Poff, 2002; Liu et al., 2014). Flooding affects phytoplankton abundance and community composition, whereas fluctuations in water levels cause quick growth of certain algal species (Avigliano et al., 2014). Nevertheless, there are very few studies regarding the effect of flood stress on aquatic ecosystems (Lake, 2011).

Flooding of Lake Nasser in Egypt occurs once a year during August because of high outflow from the Ethiopian highlands instigated by the yearly monsoonal weather pattern. It is worthmentioning that the greatest factor affecting the ecosystem of Lake Nasser is the yearly flood of the Nile River, which, in turn, affects the resident phytoplankton abundance and components (Hussian et al., 2016).

Many studies have examined plankton community structure and biochemical constituents of Lake Nasser (Mageed \& Heikal 2006; Khalifa $\boldsymbol{e t}$ al., 2015; Hussian $\boldsymbol{e} t$ al., 2016; Abd El-Hady et al., 2016; AbdelGawad \& Abdel-Aal 2018; Hegab et al.,2020). Phytoplankton represent at least one quarter of the biomass of the world's vegetation, and any changes in phytoplankton composition affect the abundance and diversity of food web structures in aquatic ecosystems (Leterme et al., 2006). The major phytoplankton community structure in Lake Nasser belongs to Cyanobacteria, followed by Bacillariophyceae and Chlorophyceae. Total phytoplankton numbers is reported to be higher in the post-flood period (Abdel Gawad \& Abdel-Aal, 2018). Remarkably, Phytoplankton abundances of Lake Nasser under the present flood regime are similar to flood systems in South America (Train \& Rodrigues, 1997) where sporadic peaks of phytoplankton occur during high water loading. Nevertheless, the general pattern of phytoplankton abundance differs considerably in the Amazon River (Huszar \& Reynolds, 1997), where high planktonic density during low water is altered to a sparser community structure by the dilution effect of high water ( Cardoso et al., 2012).

Phytoplankton biochemistry and physiological condition determine the quality of food for consumers (Lee et al., 2017). The relative amounts of metabolic products (proteins, carbohydrates, and lipids) are closely linked to environmental and nutrient conditions (Juneja et al., 2013). Protein is the primary biochemical constituent of phytoplankton at some khors along the shoreline of Lake Nasser; an evidence that indicates a physiologically healthy phytoplankton population with high growth rates (Abd El-Hady et al., 2016). Organic matter contents of phytoplankton extensively used to indicate the trophic state of the ecosystems (Akhil et al., 2013; Renjith et al., 2013). Fixation of carbon, the primary element in organic matter (Sayre, 2010) has been demonstrated to control the size and biochemical composition of phytoplankton species (Armstrong et al., 2001). The present study was conducted to analyze the phytoplankton species composition and their biochemical constituents during flooding of Lake Nasser. 


\section{MATERIALS AND METHODS}

\section{Study area and sampling sites}

Lake Nasser, a monomictic subtropical lake, located at $20.45-23.97^{\circ} \mathrm{N}, 30.12-33$. $25^{\circ} \mathrm{E}$, is the second largest man-made lake in the world. It is distinguished by its long narrow shape with dendritic embayments called khors. A single circulation period occurs from November through March (Craig, 2000). This area is classified as hyper-arid with infrequent rainfall events (Kottek $\boldsymbol{e t}$ al., 2006). Water samples, obtained from Lake Nasser's main channel during the flood period in August 2017 including surface, $10 \mathrm{~m}$ and $20 \mathrm{~m}$ depth and two meters before the bottom of the lake (depth of each site showed in table 1), were collected from 5 sites (Fig. 1). These sites include: The High Dam (Site 1), Wadi-Abyad (Site 2), El-Madiq (Site 3), Tushka (Site 4), and Abu-Simble (Site 5).

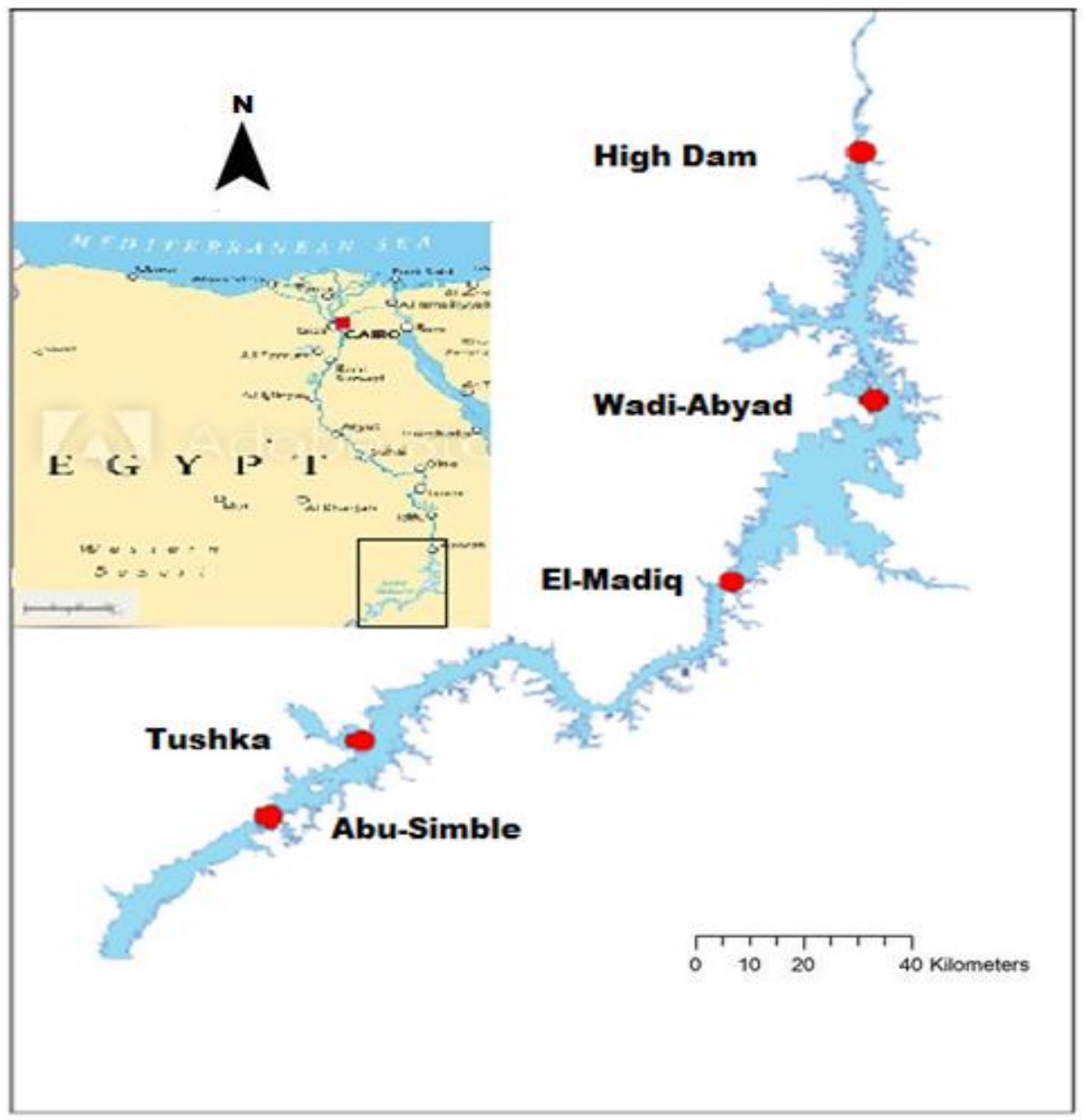

Fig. 1. Map of Lake Nasser showing the selected sites at the main channel.

\section{Abiotic parameters}

Water temperature and $\mathrm{pH}$ were measured in situ using a Hydrolab Multi Set 430i WTW. Transparency was then measured using a black-white Secchi disk. Total dissolved 
solids (TDS) and dissolved oxygen (DO) were measured according to methods described in ABHA (2005). The results of the nutrients (nitrite, nitrate and phosphate) were obtained with the chemistry laboratory of the Freshwater and Lakes Division from the work plan of the National Institute of Oceanography and Fisheries (NIOF). Physicochemical parameters, phytoplankton standing crop and its biochemical constituents, including carbohydrates, proteins, lipids, total biochemical content and biopolymeric particulate organic carbon, were determined as an average of the results obtained at different water levels.

\section{Biotic parameters}

\subsection{Phytoplankton}

Phytoplankton identification and abundances were determined by first collecting 1 liter water samples that were immediately preserved with formalin. In the laboratory, each sample was poured into a 1 litre capacity cylinder and left for five days with an addition of Lugol's iodine solution. Identification and enumeration (cells $1^{-1}$ ) of phytoplankton species was accomplished using $100 \mathrm{ml}$ aliquots of each examined sample using an inverted microscope following the methods of APHA (2005). phytoplankton species were identified according to published protocols of Hendey (1964), Bourrelly (1968), Bourrelly (1981), Sheath and Wehr (2003) and Taylor et al. (2007).

\subsection{Biochemical content of phytoplankton}

For biochemical constituent analysis, water samples were filtered using $100 \mu \mathrm{m}$ zooplankton net to remove macrozooplankton, and then filtered using GF/F Whatman filter paper $(0.7 \mu \mathrm{m})$. Filtered samples were preserved in ice. A Biuret test was used for total protein analysis using bovine albumin as a standard (David James \& Hazelm, 1994). Total carbohydrate content was determined by the phenol-sulfuric acid hydrolysis method as described by Dubois et al. (1956), using glucose as standard, whereas lipid content was estimated by the sulphophosphovanillin procedure using cholesterol as the calibration standard (Chabrol \& Castellano, 1961). Protein, carbohydrate, and lipid concentrations were converted to equivalent carbon using $0.40,0.49$, and $0.75 \mathrm{mgC} / \mathrm{l}$ conversion factors, respectively (Fabiano \& Danovaro, 1994). Biopolymeric carbon abundance refers to the sum of carbon in proteins, carbohydrates and lipids (Fichez, 1991; Fabiano et al., 1995).

\section{Data analysis}

The physico-chemical parameters, the phytoplankton data and the biochemical components were drawn up in the form of one matrix and were analyzed by Principle Component Analysis (PCA) using XLstat 2016 software. 


\section{RESULTS AND DISCUSSION}

\section{Abiotic paramerters}

Physico-chemical parameters of the aquatic environment of Lake Nasser are dependent on flood events (Hussian $\boldsymbol{e t}$ al., 2016). Principle Component Analysis (PCA) was initially performed on 8 environmental variables with total phytoplankton species, five phytoplankton classes and their biochemical constituents (Fig. 2). Limnological flood characteristics indicated that the average depth values ranged from $57.5 \mathrm{~m}$ at Site 5 (Abu-Simble) to $106 \mathrm{~m}$ at Site 1 (High Dam). The decrease in the depth of water in the southern sites of the lake may be attributed to the deposition of large amounts of silt loaded with flood water. Hegab et al. (2020) concluded that flood affects the riverine region (southern part) of Lake Nasser which, in turn, changes its ecosystem.

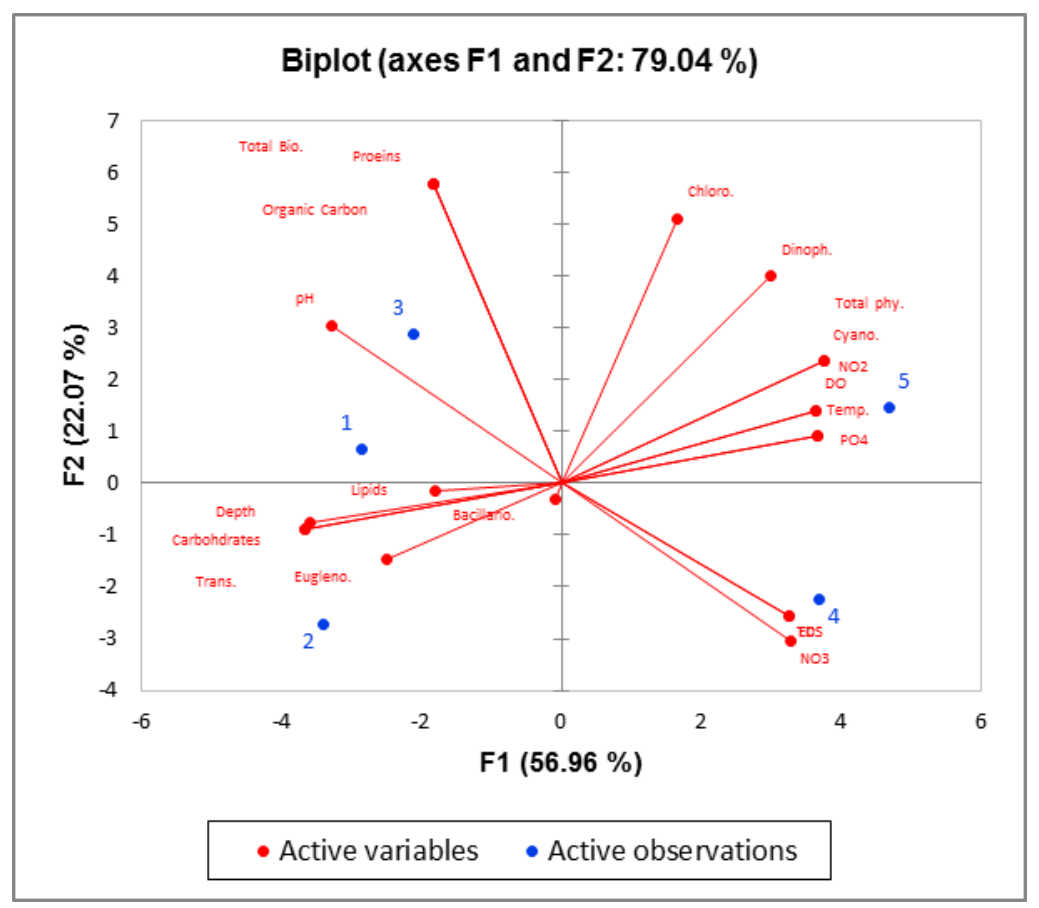

Fig. 2. Principal component analysis (PCA) between environmental and biological variables in the different sampling sites of Lake Nasser during the flood. Abbreviations are: water temperature (Temp.), dissolved oxygen (DO), transparency (Trans.), total dissolved solids (TDS), nitrite $\left(\mathrm{NO}_{2}\right)$, nitrate $\left(\mathrm{NO}_{3}\right)$, phosphate $\left(\mathrm{PO}_{4}\right)$, total phytoplankton (Total phy.), total biochemical content (Total Bio.), Cyanophyceae (Cyano.), Bacillariophyceae (Bacillario.), Chlorophyceae (Chloro.), Dinophyceae (Dinoph.), and Euglenophyceae (Eugleno.)

Water temperature average values ranged from 26.3 to $27.4^{\circ} \mathrm{C}$. Moreover, transparency values fluctuated from $0.6 \mathrm{~cm}$ at Site 5 to $420 \mathrm{~cm}$ at Site 1, noting that low water transparency in upstream sites (southern part) is due to the effect of high turbidity resulting from the flood (Gharib \& Abdel-Halim, 2006) . Salem (2011) related the less 
turbidity values in the northern sites (lacustrine portion) of Lake Nasser to the decrease of water velocity which leads to settling of silt. $\mathrm{pH}$, always in the alkaline side, varied between7.8 and 8.0. Dissolved oxygen is one of the main factors affecting the survival of aquatic organisms (bacteria, plankton and fish). Lake water was well oxygenated during flood time as dissolved oxygen ranged between $5.8 \mathrm{mg} / \mathrm{l}$ at Site 2 to $6.6 \mathrm{mg} / \mathrm{l}$ at Site 5 . As shown in PCA analysis, DO was positively correlated with total phytoplankton, Cyanobacteria, Dinophyceae, Chlorophyceae, water temperature and TDS ( $\mathrm{r}=0.70,0.70$, $0.67,0.31,0.52$ and 0.80 , respectively), where it correlated negatively with Euglenophyceae, total biochemical contents, transparency and $\mathrm{pH}(\mathrm{r}=-0.87,-0.40,-0.77$ and -0.70 respectively). The differences in values of TDS in different sampling sites during the flood period were very slight (Table1). They correlated positively with total phytoplankton and negatively with all components of biochemical contents of phytoplankton.

Table 1. Average \pm SD of physico-chemical Characteristics of Lake Nasser during the flood season.

\begin{tabular}{lccccc}
\hline & Site 1 & Site 2 & Site 3 & Site 4 & Site 5 \\
\hline Depth $(\mathrm{m})$ & 106 & 79 & 73 & 60 & 57.5 \\
Temp. $\left({ }^{\circ} \mathrm{C}\right)$ & $26.3 \pm 3.99$ & $26.8 \pm 4.41$ & $27.0 \pm 4.75$ & $27.4 \pm 4.08$ & $27.4 \pm 4.8$ \\
Trans. $(\mathrm{cm})$ & 420 & 410 & 160 & 1.3 & 0.6 \\
pH & $8.0 \pm 0.48$ & $7.9 \pm 0.69$ & $8.0 \pm 0.69$ & $7.8 \pm 0.51$ & $7.8 \pm 0.59$ \\
DO $\quad(\mathrm{mg} / \mathrm{l})$ & $6.24 \pm 1.87$ & $5.78 \pm 2.8$ & $6.0 \pm 2.78$ & $6.47 \pm 1.49$ & $6.60 \pm 1.06$ \\
TDS $(\mathrm{mg} / \mathrm{l})$ & $163.8 \pm 6.2$ & $162.3 \pm 10.7$ & $159.9 \pm 8.2$ & $166.9 \pm 6.2$ & $166.9 \pm 2.0$ \\
\hline
\end{tabular}

Nitrite ranged between a low value of $0.3 \mu \mathrm{g} / \mathrm{l}$ at Site 2 to a high of $9.3 \mu \mathrm{g} / \mathrm{l}$ at Site 5; nitrates average values varied from 22.7 to $82.17 \mu \mathrm{g} / \mathrm{l}$ whereas, phosphates ranged from 4.48 to $7.11 \mu \mathrm{g} / \mathrm{l}$. Furthermore, temperature, $\mathrm{pH}$, and high nutrient concentrations were the most important factors affecting phytoplankton species distribution in Lake Nasser. These parameters affect other characteristics of water, including photosynthetic activity of phytoplankton and solubility of certain gases, which, in turn, influence other aquatic organisms (Abd El-Hady et al., 2016; Abdel Gawad \& Abdel-Aal, 2018).

\section{Biotic paramerters}

\subsection{Phytoplankton}

A total of 68 phytoplankton taxa were identified in Lake Nasser during flood, including Cyanobacteria (12 taxa), Bacillariophyceae (18 taxa), Chlorophyceae (22 taxa), Dinophyceae (9 taxa), and Euglenophyceae (7 taxa); all of which are listed in Table 2. Phytoplankton dominated by Cyanobacteria nearly at all lake depths (Table 3), followed by Bacillariophyceae, except for El-Madiq (Site 3) where Chlorophyceae attained the 
Table 2. List of phytoplankton species recorded in Lake Nasser during the flood season. Species

\section{Cyanobacteria}

Microcystis. aeruginosa Kutz. M. flosaquae (Wittrock) Kirchner Microcystis viridis (A.Braun) Lemmermann Merismopedia tenuissima Lemmermann

M.glauca (Ehrenberg)Nageli

Snowella lacustris (Chodat) Komárek \& Hindák

Chroococcus minutus (Kutzing) Nageli

Planktolyngbya limnetica Lemmermann

Oscillatoria princeps Vaucher

Phormidium lucidum Kützing

Oxynema acuminatum (Gomont) Chatchawan

Aphanizomenon flosaquae Ralfs ex Bornet \&

Flahault

Bacillariophyceae

Aulacoseira granulata (Ehr.) Sim

A. granulata var. angustissima (O.Müller)

Simonsen

Cyclotella kutzingiana var. meneghiniana

(Kützing) Brun

Epithemia operculata (C.Agardh) Ruck \& Nakov

Pantocsekiella ocellata (Pantocsek) K.T.Kiss \&

Ács

Lindavia glomerata (H.Bachmann) Adesalu \&

Julius

Cyclotella kutzingiana var. meneghiniana

(Kützing) Brun

Lindavia bodanica (Eulenstein ex Grunow)

T.Nakov

Ulnaria ulna (Nitzsch) Compère

$U$. acus (Kützing) Aboal

Microcostatus krasskei (Hustedt) J.R

Kobayasiella subtilissima (Cleve) Lange-Bertalot

Achnanthidium pyrenaicum (Hustedt)

H.Kobayasi

Platessa conspicua (Ant.Mayer) Lange-Bertalot

Epithemia turgida (Ehrenberg) Kützing

Encyonema minutum (Hilse) D.G.Mann

Nitzschi. acicularis W.Smith

N. filiformis (W. Smith) Grun

Chlorophyceae

Chlorella vulgaris Beijerinck

Auxenochlorella pyrenoidosa (H.Chick) Molinari

Crucigenia quadrata Morren

Willea rectangularis (A.Braun) D.M.John
Crucigenia tetrapedia(Kirchner)W.\& G.S.West

Monoraphidium convolutum (Corda)

Ankistrodesmus falcatus RalfsCorda

A. falcatus var. mirabilis West

Neglectella solitaria (Wittrock) Stenclová \&

Kastovsky

Oocystis elliptica W. West

O. lacustris Chodate

Mucidosphaerium pulchellum (H.C.Wood) C.Bock

Staurastrum anatinum var. longibrachiatum West \&

G.S.West

Tetradesmus dimorphus (Turpin) M.J.Wynne

Scenedesmus ecornis (Ehrenberg) Chodat

Tetraëdron caudatum (Corda) Hansgirg

T. minimum (A.Braun) Hansgirg

Pediastrum. duplex Meyen

Roya obtusa (Brébisson) West \& G.S.West

Actinastrum hantzschii Lag.

Lagerheimia citriformis (J.W.Snow) Collins

Stauridium tetras var. tetraodon (Corda) J.D.Hall \&

Karol

\section{Dinophyceae}

Ceratium hirundinella (O.F.Müller) Dujardin

Ceratium brachyceros Daday

Ceratium hirundinella f. austriacum (Zederbauer)

Bachmann

Peridiniopsis kulczynskii (Woloszynska) Bourrelly

Glenodiniopsis steinii Woloszynska

Gonyaulax apiculata Entz

Palatinus apiculatus (Ehrenberg)

Craveiro,Calado,Daugbjerg\& Moestrup

P. gatunense Nygaard

Parvodinium umbonatum (F.Stein) Carty

Euglenophyceae

Euglena viridis Ehrenberg

E. sanguinea Ehrenberg

E. gracilis Klebs

E. clara Skuja

Lepocinclis acus (O.F.Müller) B.Marin \& Melkonian Euglenaformis proxima (P.A.Dangeard) M.S.Bennett \& Triemer E. subehrenbergii Skuja 
second highest class. Dinophyceae and Euglenophyceae are rare classes in the studied area (Fig. 3). The dominance of Cyanobacteria over other classes is attributed to the flood effect, a verification that coorelates with that of Mccullough et al. (2012) who developed and evaluated a remote monitoring protocol for water clarity in large lakes from May to September for three years, recording the most consistent results in August. This suggests that, during the other months, unstable seasonal lake conditions and inter-annual differences in algal productivity occurred. The dominance of Cyanobacteria was assessed by Jekatierynczuk-Rudczyk et al. (2014) in determining the trophic status of lakes. The current study confirmed conditions of high Cyanobacterial density, especially at AbuSimbel (Site 5), where Cyanobacteria formed $97 \%$ of the total phytoplankton population and was accompanied by the highest value of major nutrients [nitrite $(9.3 \mu \mathrm{g} / \mathrm{l})$, nitrate $(71.2 \mu \mathrm{g} / \mathrm{l})$ and phosphate $(7.1 \mu \mathrm{g} / \mathrm{l}]$, the lowest transparency $(0.6 \mathrm{~cm})$ and the highest reading of dissolved oxygen $(6.6 \mathrm{mg} / \mathrm{l})$. This suggests that increases in nutrient availability and dissolved oxygen during flooding may lead to proliferation of certain

Table 3. Density of different phytoplankton groups at various depths of different sites along the main channel of Lake Nasser during the flood period.

\begin{tabular}{|c|c|c|c|c|c|c|}
\hline & & $\begin{array}{l}\text { Cyanophyceae } \\
\text { (units.10 }{ }^{3} \mathrm{I}^{-1} \text { ) }\end{array}$ & $\begin{array}{l}\text { Bacillariophyceae } \\
\left(\text { cells.10 } 1^{3} \mathrm{I}^{-1}\right)\end{array}$ & $\begin{array}{l}\text { Chlorophyceae } \\
\left(\text { cells.10 }{ }^{3} \mathrm{I}^{-1}\right)\end{array}$ & $\begin{array}{l}\text { Euglenophyceae } \\
\left(\text { cells.10 } 0^{3} \mathrm{I}^{-1}\right)\end{array}$ & 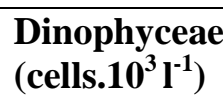 \\
\hline \multirow{4}{*}{ 总 } & Surface & 11570 & 260 & 520 & 130 & 260 \\
\hline & $10 \mathrm{~m}$ & 18190 & 130 & 650 & 260 & 260 \\
\hline & $20 \mathrm{~m}$ & 9750 & 390 & 130 & 0 & 130 \\
\hline & Bottom & 0 & 8060 & 0 & 0 & 0 \\
\hline \multirow{4}{*}{ 党 } & Surface & 1950 & 0 & 130 & 130 & 130 \\
\hline & $10 \mathrm{~m}$ & 13000 & 520 & 0 & 390 & 0 \\
\hline & $20 \mathrm{~m}$ & 8450 & 260 & 260 & 260 & 260 \\
\hline & Bottom & 6500 & 1820 & 0 & 130 & 0 \\
\hline \multirow{4}{*}{ 总 } & Surface & 11700 & 0 & 260 & 390 & 390 \\
\hline & $10 \mathrm{~m}$ & 13000 & 0 & 2470 & 0 & 0 \\
\hline & $20 \mathrm{~m}$ & 3250 & 390 & 520 & 390 & 130 \\
\hline & Bottom & 19760 & 650 & 0 & 130 & 130 \\
\hline \multirow{4}{*}{ 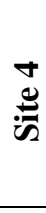 } & Surface & 30550 & 520 & 910 & 130 & 130 \\
\hline & $10 \mathrm{~m}$ & 10400 & 910 & 130 & 130 & 130 \\
\hline & $20 \mathrm{~m}$ & 17550 & 130 & 0 & 130 & 390 \\
\hline & Bottom & 10400 & 130 & 390 & 130 & 0 \\
\hline \multirow{4}{*}{ 品 } & Surface & 131430 & 3120 & 1560 & 0 & 4290 \\
\hline & $10 \mathrm{~m}$ & 61100 & 0 & 0 & 0 & 0 \\
\hline & $20 \mathrm{~m}$ & 143650 & 0 & 0 & 0 & 0 \\
\hline & Bottom & 0 & 130 & 520 & 130 & 520 \\
\hline
\end{tabular}


Cyanobacteria species over other classes of phytoplankton. Paerl et al. (2016) attributed the dramatic increase in phytoplankton abundance to increased loading by phosphate and nitrogen sources during flood season.

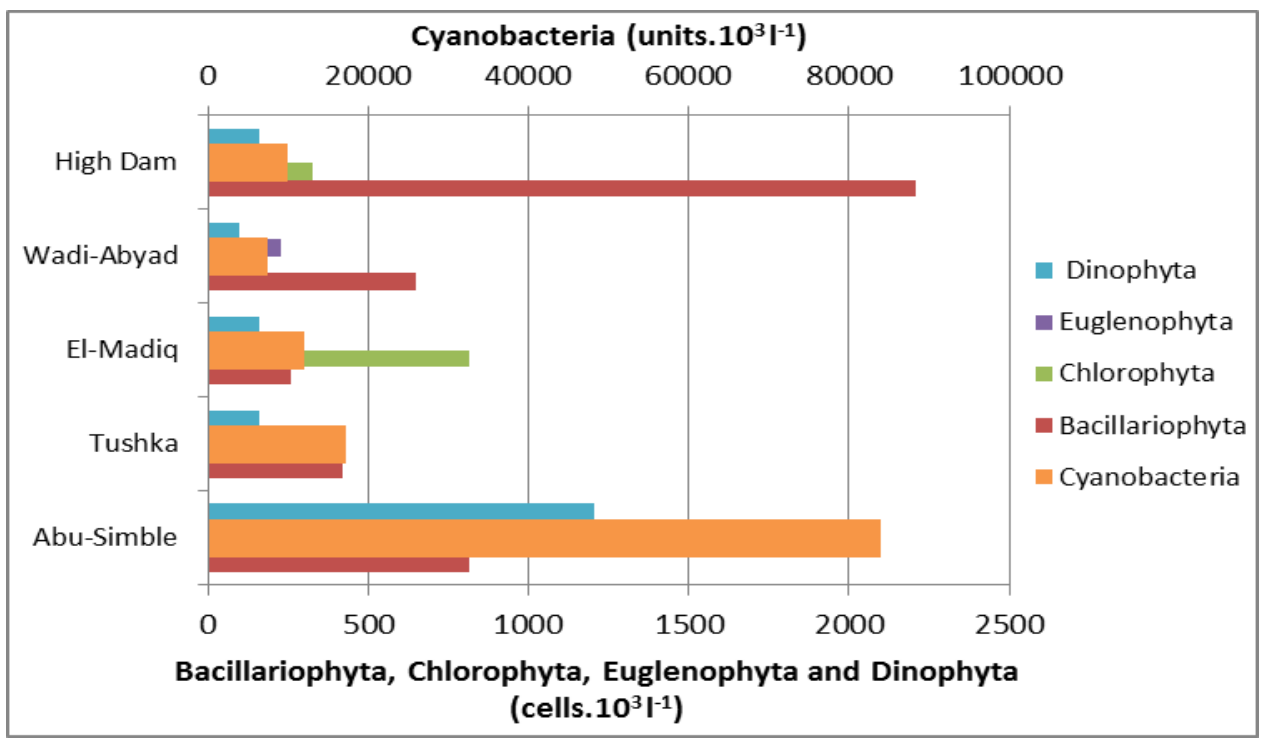

Fig. 3. Average density of different phytoplankton groups at the selected sites along the main channel of Lake Nasser during the flood.

Cyanobacteria populations in Lake Nasser dominated by Microcystis aeruginosa, Planktolyngbya limnetica, and Oscillatoria princeps (Fig. 4). Hamed (2000) attributed the factors responsible for blue-green algae blooms in Lake Nasser to the high eutrophication of lake water with high percentages of phosphate and nitrate, in addition to $\mathrm{pH}$ values tending towards alkalinity and suitable water temperature. Moreover, the expected toxicity of the dominant species Microcystis aeruginosa and Oscillatoria princeps was assessed by Marrez et al. (2016) in different Egyptian aquatic ecosystems (Kafr El-Zayat, El-Rasua and El-Khadra) and by Zaher (2012) at Wadi El-Rayian Lake. Thus, the dominance of these species and the changes in the present flood regime by disturbances such as the Grand Ethiopian Renaissance Dam construction are predicted to influence the Lake Nasser aquatic ecosystem.

This study cannot conclusively confirm that the increases in population in the phytoplankton community are merely related to the flood effect; because there are other interacting variables including the limnological characteristics of the water (temperature, $\mathrm{pH}$, transparency, and nutrient supply) and grazing rate. However, the potential for algal proliferation occurs after flooding when nutrient availability is increased and water residence time is sufficiently long to allow algal blooms to form and accumulate (Paerl $\boldsymbol{e t}$ al., 2016). Nitrite, nitrate, and phosphate are positively correlated $(\mathrm{r}=0.95,0.55$, and 0.79 , respectively) with Cyanobacteria blooms in the lake. The study of Mihaljević $\boldsymbol{e t ~ a l}$. (1999) on Lake Danubian concluded that flooding caused formation of dense algal 
blooms of Cyanobacteria. Whereas, a decade later, the study of Mihaljević et al. (2009) on the same lake, concluded that flooding has a dual impact on development of phytoplankton. In their study ( 2009), the previous authors reported that flooding of Lake Danubian in early spring stimulated phytoplankton development, but flood pulses in May and June introduced a dilution affect whereby nutrient concentrations decreased, resulting in detection of a significantly lower phytoplankton biomass. Thus, flooding pulses can be considered as a type of ecosystem disturbance.

Within our data set, a strong positive correlation between total phytoplankton and Cyanobacteria $(r=0.99)$ as the dominant class, while DO $(r=0.70)$ indicates that oxygen production resulting from phytoplankton blooms exceeds ten times the amount consumed (Hardy 1973). Oxygen production supplies the heterotrophic organisms and the ecosystem in general with added energy because increases in phytoplankton biomass in the aquatic system result in an increase in the amount of DO as a result of photosynthesis during daylight (Kunlasak et al., 2013). Proliferation of Cyanobacteria, however, increased the turbidity of water in the lake as confirmed by a strong negative correlation between transparency and blue-green algae populations $(\mathrm{r}=-0.6)$.

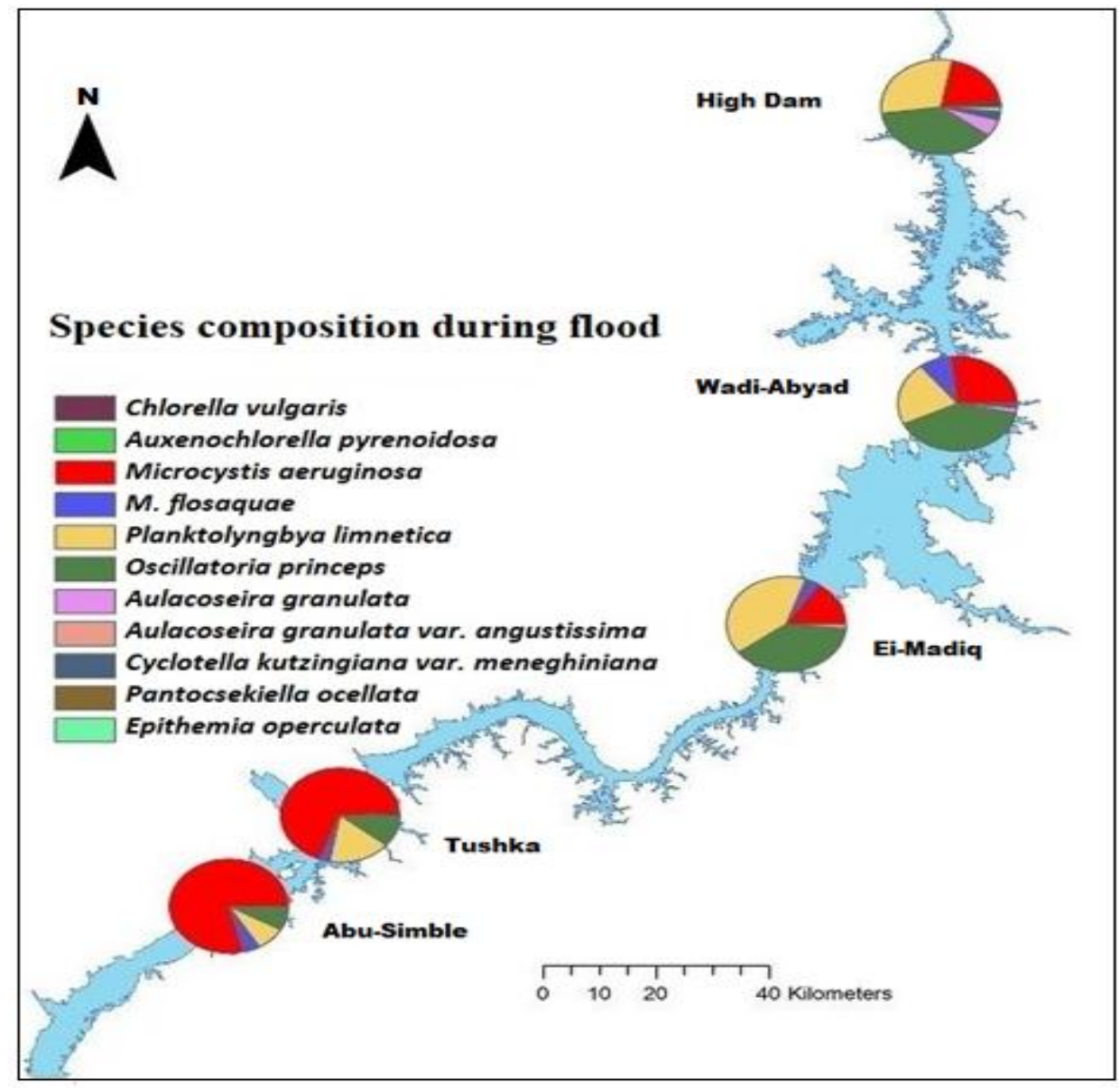

Fig. 4. Dominant phytoplankton species inhabiting Lake Nasser across different sites during the flood period. 
Green algae in Lake Nasser were dominated by Chlorella vulgaris, Auxenochlorella pyrenoidosa, Crucigenia quadrata, Ankistrodesmus convolutes, and Dictyosphaerium pulchellum as well. Wadi-Abyad site is characterized by a considerable lower density and diversity of green algae compared to other examined sites (Fig. 3). This observation is accompanied with complete depletion of nitrite and high concentrations of ammonium, nitrate, and high water temperature. Nitrogen is considered a limiting factor affecting phytoplankton growth (Livingston $\boldsymbol{e t}$ al., 2002) and the higher values of nitrogen inhibit growth of certain algal species (Karthikeyan et al., 2010).

The highest abundances of diatoms documented at the High Dam site $\left(2210 \times 10^{3}\right.$ cell $^{-1}$ ) and the lowest value of $260 \times 10^{3}$ cell $^{-1}$ were noticed at El-Madiq site (Fig. 3). During the studied flood event, the most common recorded species of diatoms were Aulacoseira granulata, Aulacoseira granulata var. angustissima, Cyclotella kutzingiana var. meneghiniana, Pantocsekiella ocellata and Epithemia operculata. Habitat heterogeneity effects on plankton communities, particularly phytoplankton in flood plains, are direct results of the fluctuation of water levels in the aquatic system (Junk $\boldsymbol{e} t$ al., 2006). Similar to other higher planktonic organisms, phytoplankton density and abundance during flood periods are driven by the force of the flood pulse, which affect the limnological and biological properties of water (Train \& Rodrigues, 1997; Thomaz et al., 2007).

\subsection{Biochemical content of phytoplankton}

Biopolymeric particulate organic carbon, along all detected depths of the five sites, was related to the high extent of the high biopolymeric $\mathrm{C}$ of phytoplankton proteins (Table 4). High average values of biopolymeric particulate organic carbon $(37.15 \mathrm{mg} / \mathrm{l})$ and total biochemical content $(91.29 \mathrm{mg} / \mathrm{l})$ detected at Site 3 (Fig. 5), may be due to the optimum nutrient values of nitrite $(0.479 \mu \mathrm{g} / \mathrm{l})$ and phosphate $(5.149 \mu \mathrm{g} / \mathrm{l})]$ encountered there. However, total biochemical content and biopolymeric particulate organic carbon decreased at Site 5 (Abu-Simble) which associated with increases of nitrite and phosphate with values 9.31 and $7.11 \mu \mathrm{g} / \mathrm{l}$, respectively, accompanied with a decrease in transparency to its lowest levels $(0.60 \mathrm{~cm})$. This may be attributed to the transport of large amounts of suspended solids and nutrients into Lake Nasser by floods, allowing nutrient replenishment and changes in the amount of light necessaryfor algal growth. Elevation in the suspended matter concentration in a lake leads to greater light attenuation and, hence, a decrease in biochemical content (Tilzer et al., 1976). Light is the primary energy source during the photoautotrophic growth phase of algae to convert carbon dioxide to organic biochemical compounds (Juneja et al., 2013). A physiologically healthy phytoplankton population with high relative growth rates has minor lipid content, whereas the present findings reflect higher lipid content at all studied lake sites relative to carbohydrates, especially at Site $3(1.5 \mathrm{mg} / \mathrm{l}$ lipid versus $1.14 \mathrm{mg} / \mathrm{l}$ carbohydrate concentrations). An increase in suspended matter during flooding may lead to light- 
limited conditions, an increase in total lipid content, and a decrease in free fatty acids, alcohol, and sterol (Gordillo et al., 1998). Moreover, algae can be exposed to environmental conditions that influence growth rate and cellular composition; however, the amount of carbon fixed in lipids and carbohydrates is highly affected by nutrient availability (Juneja et al., 2013).

Table 4. Density of different biochemical contents $\left(\mathrm{mg}^{-1}\right)$ of phytoplankton at various depths of different sites along the main channel of Lake Nasser during the flood period.

\begin{tabular}{|c|c|c|c|c|c|}
\hline & & Proteins & Carbohdrates & Lipids & $\begin{array}{l}\text { Biopolymeric } \\
\text { particulate } \\
\text { organic carbon }\end{array}$ \\
\hline \multirow{4}{*}{ 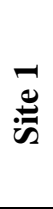 } & Surface & 102.3 & 1.28 & 1.4 & 42.6 \\
\hline & $10 \mathrm{~m}$ & 95.5 & 1.10 & 0.8 & 39.3 \\
\hline & $20 \mathrm{~m}$ & 111.4 & 1.20 & 1.0 & 45.9 \\
\hline & Bottom & 38.6 & 1.28 & 0.7 & 16.6 \\
\hline \multirow{4}{*}{ 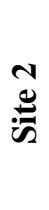 } & Surface & 36.5 & 1.20 & 1.2 & 16.1 \\
\hline & $10 \mathrm{~m}$ & 106.8 & 1.28 & 1.0 & 44.1 \\
\hline & $20 \mathrm{~m}$ & 97.7 & 1.20 & 1.4 & 40.7 \\
\hline & Bottom & 100 & 1.20 & 1.2 & 41.5 \\
\hline \multirow{4}{*}{$\stackrel{m}{\sum_{i=1}}$} & Surface & 75.0 & 1.12 & 1.8 & 31.9 \\
\hline & $10 \mathrm{~m}$ & 99.9 & 1.12 & 1.9 & 42.0 \\
\hline & $20 \mathrm{~m}$ & 88.6 & 1.20 & 1.4 & 37.1 \\
\hline & Bottom & 91 & 1.15 & 0.9 & 37.6 \\
\hline \multirow{4}{*}{ 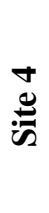 } & Surface & 74.0 & 1.12 & 1.1 & 31.0 \\
\hline & $10 \mathrm{~m}$ & 84.1 & 1.12 & 1.0 & 34.9 \\
\hline & $20 \mathrm{~m}$ & 59.1 & 1.20 & 1.3 & 25.2 \\
\hline & Bottom & 70.5 & 1.04 & 1.4 & 29.8 \\
\hline \multirow{4}{*}{ 年 } & Surface & 97.7 & 1.12 & 1.2 & 40.5 \\
\hline & $10 \mathrm{~m}$ & 81.8 & 1.12 & 1.1 & 34.1 \\
\hline & $20 \mathrm{~m}$ & 84.1 & 1.20 & 0.9 & 34.9 \\
\hline & Bottom & 81.1 & 1.12 & 0.5 & 33.4 \\
\hline
\end{tabular}

Maximum protein and lipid contents of 88.64 and $1.5 \mathrm{mg} / \mathrm{l}$, respectively, were detected at Site 3 in the lake (El-Madiq), which may be related to the increase of Chlorophyceae biomass $\left(812.5\right.$ cells $\left.\times 10^{3} 1^{-1}\right)$, where Chlorella was the dominant species. Many phytoplankton have the ability to produce triacylglycerols up to $50 \%$ of dry cell weight as a storage lipid under stressful environmental conditions (Abou-Shanab et al., 2011; Yun et al., 2014). Chlorophyceae species, isolated from freshwater lakes in Hungary and Romania (Central Europe), may contain $40 \%$ dry weight of protein, whereas Chlorella vulgaris can accumulate a high lipid content $(42.1 \%)$ with a $77.4 \%$ $\mathrm{C}^{16}-\mathrm{C}^{18}$ fatty acid profile (Selvarajan et al., 2015). 
A high positive correlation was detected between carbohydrates and transparency as well as $\mathrm{pH}$ in Lake Nasser ( $\mathrm{r}=0.97$ and 0.79 , respectively). Moreover, Bacillariophyceae correlate positively with carbohydrates $(\mathrm{r}=0.61)$. Diatoms produce large quantities of extracellular polymeric substances including polysaccharides and glycoproteins, thus providing organic carbon to heterotrophs (Haynes et al., 2007).

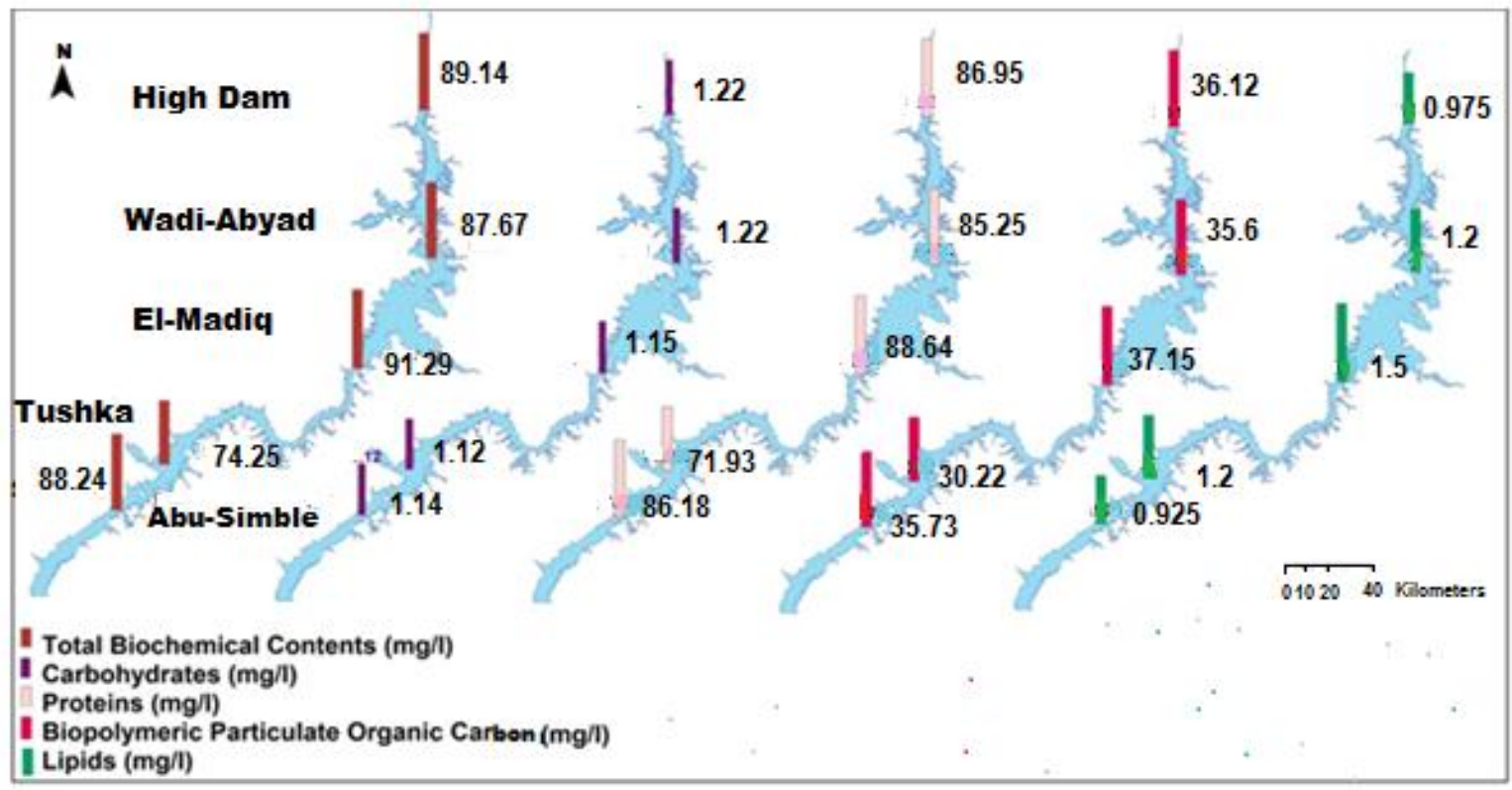

Fig. 5. Average of total biochemical content, carbohydrate, proteins, biopolymeric particulate organic carbon and lipids of phytoplankton during the flood season at Lake Nasser.

Generally, PCA (Fig. 2) shows that the distribution of all variables with axis F1 $(56.96 \%)$ and F2 (22.07\%) determined the significant relationship between variables. It suggested that the most significant parameters affecting total phytoplankton distribution especially Cyanobacteria were: temperature, $\mathrm{DO}$ and the major nutrients $\left(\mathrm{NO}_{2}\right.$ and $\left.\mathrm{PO}_{4}\right)$ especially in Site 5 (Abu-Simble) which confirmed the strong effect of flood on phytoplankton distribution especially at that specific site of the lake. A negative correlation between protein contents, organic carbon and total biochemical contents and $\mathrm{NO}_{3}$. PCA indicate that there was correlation between Sites 1 and 3 with total biochemical contents, total proteins and organic carbon and $\mathrm{pH}$ as environmental parameter. At Site 2 transparency of water shows a correlation between carbohydrates and lipid contents of phytoplankton especially class Bacillariophyceae and Euglenophyceae.

\section{CONCLUSION}

Changes in flood pulses at Lake Nasser may cause changes in the entire aquatic ecosystem. The present results suggest that flooding of Lake Nasser positively changes 
the lake water quality by adding more dissolved oxygen and nutrients, thereby affecting phytoplankton composition, distribution, and abundance at all sites. Moreover, flooding influences the biochemical structure of algae inhabiting Lake Nasser, leading to an elevation in the minor lipid cellular composition relative to carbohydrates. Remarkably, the high protein and lipid contents and high total biochemical content of algae inhabiting El-Madiq site, together with the high abundances of Chlorophyceae are highly noted. This study provides a baseline for the phytoplankton community structure in Lake Nasser during flood periods, prior to the anticipated effects of altered water flow as a result of filling of the Grand Ethiopian Renaissance Dam upstream along the Blue Nile.

\section{ACKNOWLEDGMENTS}

We thanks to members of chemistry lab for providing with some physicochemical parameters data. The authors express their deep appreciations to Dr. Walid Aly, Fisheries Division, National Institute of Oceanography and Fisheries (NIOF) for doing Arc-GIS map.

\section{REFERENCES}

Abd El-Hady, H.H.; Fathey, S.A.; Ali, G.H. and Gabr Y.G. (2016). Biochemical profile of phytoplankton and its nutritional aspects in some khors of Lake Nasser, Egypt. Egypt. J. Basic Appl. Sci., 3(2):187-193.

AbdelGawad, S.S. and Abdel-Aal, E.I. (2018). Impact of Flood Cycle on Phytoplankton and Macroinvertebrates Associated with Myriophyllum spicatum in Lake Nasser Khors (Egypt). J. Biol. Sci., 18(2):51-67.

Abou-Shanab, R.A.; Hwang, J.-H.; Cho, Y.; Min, B. and Jeon, B-H. (2011). Characterization of microalgal species isolated from fresh water bodies as a potential source for biodiesel production. Appl. Energy, 88(10):3300-3306.

Akhil, P., Nair, M.P. and Sujatha, C. (2013). Core sediment biogeochemistry in specific zones of Cochin Estuarine System (CES). J. Earth Sys. Sci., 122(6):1557-1570.

APHA. (2005). Standard Methods for the Examination of Water and Wastewater. Centennial Edition, APHA, AWWA, WEF, Washington, DC.

Armstrong, R.A.; Lee, C.; Hedges, J.I.; Honjo, S. and Wakeham, S. G. (2001). A new, mechanistic model for organic carbon fluxes in the ocean based on the quantitative association of POC with ballast minerals. Deep Sea Research Part II: Trop. Stud. Oceanog., 49(1-3):219-236.

Avigliano, L.; Vinocur, A.; Chaparro, G.; Tell, G. and Allende, L. (2014). Influence of reflooding on phytoplankton assemblages in a temperate wetland following prolonged drought. J. Limnol., 73:247-262.

Bourrelly, P. (1981). Fresh Water Algae: Chrysophyeae, Phaeophyceae, Xanthophyceae and Diatoms. Vol. II, N. Boube's and Co., Paris, 517pp.

Bourrelly, P. (1968). Les algues dl'eau douce. Tome 2: algues jaunes et brunes.

Cardoso, S. J., Roland, F., Loverde-Oliveira, S. M., \& de Moraes Huszar, V. L. (2012). Phytoplankton abundance, biomass and diversity within and between Pantanal wetland habitats. Limnologica, 42(3):235-241.

Chabrol, E. and Castellano, A. (1961). SPV method for estimation of total serum lipid. J. Lab. Clin. Med, 57, 300. 
Craig, J.F. (ed.) (2000). Sustainable fish production in Lake Nasser: ecological basis and management policy. ICLARM Conf. Prof. 61, WorldFish Center, Penang, Malaysia. 184 pp.

David James, H. and Hazel, P. (1994). Problem solving in analytical biochemistry. $3^{\text {rd }}$ ed. ed: Longman; 488pp.

Dubois, M.I.; Gilles, K.A.; Hamilton, J.K.; Rebers, P.T. and Smith, F. (1956). Colorimetric method for determination of sugars and related substances. Anal. Chem., 28(3):350-6.

Euripidou, E. and Murray, V. (2004). Public health impacts of floods and chemical contamination. J. Public Health, 26(4):376-383.

Fabiano, M.; Danovaro, R. and Fraschetti, S. (1995). Temporal trend analysis of the elemental composition of the sediment organic matter in subtidal sandy sediments of the Ligurian Sea (NW Mediterranean): A three years study. Cont. Shelf Res., 15:1453-1469.

Fabiano, M. and Danovaro, R. (1994). Composition of organic matter in sediments facing a river estuary (Tyrrhenian Sea): relationships with bacteria and microphytobenthic biomass. Hydrobiologia, 277(2):71-84.

Fichez, R. (1991). Composition and fate of organic matter. Oceanol. Acta, 14(4):369-377.

Gharib, S.M. and Abdel-Halim, A.M. (2006). Spatial variation of phytoplankton and some physico-chemical variables during the highest flood season in Lake Nasser (Egypt). Egypt. J. Aquat. Res., 32(1):246-263.

Gordillo, F. J.; Goutx, M.; Figueroa, F. L. and Niell, F. X. (1998). Effects of light intensity, $\mathrm{CO}_{2}$ and nitrogen supply on lipid class composition of Dunaliella viridis. J. Appl. Phycol., 10(2):135-144.

Hamed, A. (2000). Early warning on the blooming of phytoplankton inhabiting Lake Nasser Tushka area monitoring by remote sensing imagery. Egypt. J. Phycol., 1:121-132.

Hardy, J. T. (1973). Phytoneuston Ecology of a Temperate Marine Lagoon 1. Limnol. Oceanogr., 18(4):525-533.

Haynes, K.; Hofmann, T.A.; Smith, C.J.; Ball, A. S.; Underwood, G. J. and Osborn, A. M. (2007). Diatom-derived carbohydrates as factors affecting bacterial community composition in estuarine sediments. Appl. Environ. Microbiol., 73(19): 6112-6124.

Hegab, M.H.; Khalifa, N. and Aly, W. (2020). Zooplankton communities in Lake Nasser, Egypt, under the current flood regime, before the construction of Grand Ethiopian Renaissance Dam (GERD). Afr. J. Aquat. Sci., 1-11.

Hendey, N. (1964). An Introductory Account of the smaller Algae of British Coastal waters. Fishery investigations, Series IV, Part V: Bacillariophyceae. Her Majesty's stationery office, London.

Hussian, A.E.M.; Howayda, H.; Toufeek, M. and Várbíró, G. (2016). Phytoplankton Structure biochemical Stoichiometry and elemantal comnosition in Lake Nasser Egypt. Int. J. Appl. Environ. Sci. Res., 11(1):211-228.

Huszar, V.L.D.M. and Reynolds, C.S. (1997). Phytoplankton periodicity and sequences of dominance in an Amazonian flood-plain lake (Lago Batata, Pará, Brasil): responses to gradual environmental change. Hydrobiologia, 346(1-3):169-181.

Jekatierynczuk-Rudczyk， E.; Zieliński， P.; Grabowska， M.; Ejsmont-Karabin, J.; Karpowicz, M. and Więcko, A. (2014). The trophic status of Suwałki Landscape Park lakes based on selected parameters (NE Poland). Environ. Monit. Assess., 186(8):51015121.

Juneja, A.; Ceballos, R.M. and Murthy, G.S. (2013). Effects of environmental factors and nutrient availability on the biochemical composition of algae for biofuels production: a review. Energies, 6(9):4607-4638.

Junk, W.J.; Da Cunha, C.N.; Wantzen, K.M.; Petermann, P.; Strüssmann, C.; Marques, M.I. et al. (2006). Biodiversity and its conservation in the Pantanal of Mato Grosso, Brazil. Aquat. Sci., 68(3):278-309. 
Karthikeyan, P.; Jayasudha, S.; Sampathkumar, P.; Manimaran, K.; Santhoshkumar, C.; Ashokkumar, S. et al. (2010). Effect of industrial effluent on the growth of marine diatom, Chaetoceros simplex (Ostenfeld, 1901). J. Appl. Sci. Environ. Manag., 14(4):3537.

Khalifa, N.; El-Damhogy, K.A.; Fishar, M.R.; Nasef, A.M. and Hegab, M.H. (2015). Vertical distribution of zooplankton in Lake Nasser. Egypt. J. Aquat. Res., 41(2): 177185.

Kottek, M.; Grieser, J.; Beck, C.; Rudolf, B. and Rubel, F. (2006). World map of the KöppenGeiger climate classification updated. Meteorol. Z., 15(3):259-263.

Kunlasak, K.; Chitmanat, C.; Whangchai, N.; Promya, J. and Lebel, L. (2013). Relationships of dissolved oxygen with chlorophyll-a and phytoplankton composition in tilapia ponds. Int. J. Geosci., 4(05):46-53.

Lake, P.S. (2011). .Drought and aquatic ecosystems: effects and responses: John Wiley \& Sons.

Lee, J. H.; Lee, D.; Kang, J. J.; Joo, H. T.; Lee, J. H.; Lee, H. W. et al. (2017). The effects of different environmental factors on the biochemical composition of particulate organic matter in Gwangyang Bay, South Korea. Biogeosciences, 14(7):1903-1917.

Leterme, S.C., Seuront, L. and Edwards, M. (2006). Differential contribution of diatoms and dinoflagellates to phytoplankton biomass in the NE Atlantic Ocean and the North Sea. Mar. Ecol. Prog. Ser., 312:57-65.

Liu, Z.; Cheng, R.; Xiao, W.; Guo, Q. and Wang, N. (2014). Effect of off-season flooding on growth, photosynthesis, carbohydrate partitioning, and nutrient uptake in Distylium chinense. PloS one, 9(9):e107636.

Liu, Z.; Cheng, R.; Xiao, W.; Wang, R.; Feng, X. and Wang, X. (2013). Effect of waterlogging on photosynthetic and physioecological characteristics of plants. Worl. For. Res., 26(3):33-38.

Livingston, R. J.; Prasad, A.K.; Niu, X. and McGlynn, S.E. (2002). Effects of ammonia in pulp mill effluents on estuarine phytoplankton assemblages: field descriptive and experimental results. Aquat. Bot., 74(4):343-367.

Lopez, O.R. and Kursar, T.A. (1999). Flood tolerance of four tropical tree species. Tree Physiol., 19(14):925-932.

Mageed, A.A.A. and Heikal, M.T. (2006). Factors affecting seasonal patterns in epilimnion zooplankton community in one of the largest man-made lakes in Africa (Lake Nasser, Egypt). Limnologica, 36(2): 91-97.

Marrez, D.A.; Naguib, M.M.; Sultan, Y.Y.; Daw, Z.Y.; Zaher, S.S. and Higazy, A.M. (2016). Phytoplankton Profile and Toxicity Assessment of Dominant Algal Species from Different Egyptian Aquatic Ecosystems. Res. J. Pharm. Biol. Chem. Sci., 7(2):14521461.

Mccullough, I.M.; Loftin, C.S. and Sader, S.A. (2012). High-frequency remote monitoring of large lakes with MODIS 500 m imagery. Remote Sens. Environ., 124:234-241.

Mihaljević, M.; Stević, F.; Horvatić, J. and Kutuzović, B.H. (2009). Dual impact of the flood pulses on the phytoplankton assemblages in a Danubian floodplain lake (Kopački Rit Nature Park, Croatia). Hydrobiologia, 618(1):77-88.

Mihaljević, M.; Getz, D.; Tadić, Z.; Živanović, B.; Gucunski, D.; Topić, J. et al. (1999). Kopački Rit-Research Survey and Bibliography. Croatian Academy of Arts and Sciences, Zagreb.

Paerl, H.W.; Gardner, W.S.; Havens, K.E.; Joyner, A.R.; McCarthy, M.J.; Newell, S.E. et al. (2016). Mitigating cyanobacterial harmful algal blooms in aquatic ecosystems impacted by climate change and anthropogenic nutrients. Harmful Algae, 54:213-222.

Poff, N.L. (2002). Ecological response to and management of increased flooding caused by climate change. Philosophical Transactions of the Royal Society of London Series A: Math. Phys. Eng. Sci., 360(1796):1497-1510. 
Renjith, K.; Joseph, M.M.; Ghosh, P.; Rahman, K.H.; Kumar, C.R. and Chandramohanakumar, N. (2013). Biogeochemical facsimile of the organic matter quality and trophic status of a micro-tidal tropical estuary. Environ. Earth Sci., 70(2):729742.

Salem T.A. (2011). Variation of water quality and phytoplankton along different zones of Aswan High Dam Reservoir. Egypt. J. Aquat. Biol. Fish., 15(2):87-104.

Sayre, R. (2010). Microalgae: the potential for carbon capture. Bioscience, 60(9):722-727.

Selvarajan, R.; Felföldi, T.; Tauber, T.; Sanniyasi, E.; Sibanda, T. and Tekere, M. (2015). Screening and evaluation of some green algal strains (Chlorophyceae) isolated from freshwater and soda lakes for biofuel production. Energies, 8(7):7502-7521.

Sheath, R.G. and Wehr, J.D. (2003). Freshwater algae of North America: ecology and classification: Academic Press.

Taylor, J.C.; Harding, W.R. and Archibald, C. (2007). An illustrated guide to some common diatom species from South Africa: Water Research Commission Pretoria.

Thomaz, S. M.; Bini, L. M. and Bozelli, R. L. (2007). Floods increase similarity among aquatic habitats in river-floodplain systems. Hydrobiologia, 579(1):001-013.

Tilzer, M.M.; Goldma, C.R.; Richards, R.C. and Wrigley, R.C. (1976). Influence of Sediment Inflow on Phytoplankton Primary Productivity in Lake Tahoe (California-Nevada). Int. Rev. gesamten Hydrobiol. Hydrograph., 61(2):169-182.

Train, S. and Rodrigues, L.C. (1997). Temporal fluctuations of the phytoplankton community of the Baía River, in the upper Paraná River floodplain, Mato Grosso do Sul, Brazil. Hydrobiologia, 361(1-3):125-134.

Yun, H.S.; Lee, H.; Park, Y.T.; Ji, M.K.; Kabra, A.N.; Jeon, C. et al. (2014). Isolation of novel microalgae from acid mine drainage and its potential application for biodiesel production. Appl. Biochem. Biotechnol., 173(8):2054-2064.

Zaher, S.S. (2012). Potential toxicity of algal blooms in Wadi El-Rayian lakes, El-Fayioum (Egypt): Ph. D. Thesis, Faculty of Science Ain Shams University, Egypt. 